\section{SURVEY OF INHIBITORS IN DIFFERENT STEPS OF PROTEIN SYNTHESIS BY MAMMALIAN RIBOSOMES}

\author{
Luis Carrasco and David Vazquez \\ Instituto de Biologia Celular, \\ Velazquez 144, Madrid 6, Spain
}

(Received for publication November 7, 1972)

An increasing number of antibiotics has been reported in the last few years to be active on $80 \mathrm{~S}$ type ribosomes ${ }^{1,2,3,4)}$. However taking into account the scarcity of data concerning the site and mode of action of these antibiotics and the enormous heterogeneity of the biological sources of $80 \mathrm{~S}$ type ribosomes in which they were tested we have considered of interest surveying a number of inhibitors in different steps of protein synthesis using in all cases the same mammalian cell-free system. We summarize in this contribution suitable methods to study the individual steps of protein synthesis by human tonsil ribosomes and present the results obtained in these systems in the presence of a number of protein synthesis inhibitors.

\section{Materials and Methods}

Human tonsil ribosomes, elongation factor 1 (EF 1) and elongation factor 2 (EF 2) were obtained and purified as previously described. ${ }^{5,6,7,8)}$ Purity of EF 2 after phosphocellulose chromatography ${ }^{7}$ was approximately $50 \%{ }^{9}$

${ }^{14} \mathrm{C}-\mathrm{Phe}$-tRNA was prepared from Escherichia coli $\mathrm{B}$ tRNA (Sigma) that was charged with ${ }^{14} \mathrm{C}$-phenylalanine $(513 \mathrm{mCi} / \mathrm{mmol})$ (The Radiochemical Centre, Amersham, England) using a partially purified supernatant preparation of E. coli. ${ }^{10} \quad$ Ac- ${ }^{14} \mathrm{C}-\mathrm{Phe}-\mathrm{tRNA}$ was prepared by acetylation of ${ }^{14} \mathrm{C}-\mathrm{Phe}$ tRNA (tRNA used for this purpose was from baker's yeast) as described by other workers ${ }^{11}$ and then separated from deacilated tRNA by $\mathrm{BD}$-cellulose chromatography following a method which basically is similar to others already described ${ }^{12}$. Ac- ${ }^{14} \mathrm{C}-\mathrm{Phe}-\mathrm{tRNA}$ of specific activity $513 \mathrm{mCi} / \mathrm{mmol}$ was obtained.

The following buffers were used in the assays described below: Buffer A (20 mM Tris- $\mathrm{HCl}, \mathrm{pH} \mathrm{7.4}$, containing $60 \mathrm{~mm} \mathrm{KCl}$ and $7 \mathrm{mM} \mathrm{MgCl}_{2}$ ), buffer $\mathrm{B}$ (50 mM Tris$\mathrm{HCl}, \mathrm{pH} 7.4$, containing $60 \mathrm{mM} \mathrm{KCl}, 11 \mathrm{~mm}$ $\mathrm{MgCl}_{2}$ and $8 \mathrm{mM}$ 2-mercaptoethanol), buffer $\mathrm{C}(20 \mathrm{~mm}$ Tris $-\mathrm{HCl}$, pH 7.4, containing 60 $\mathrm{mM} \mathrm{KCl}$ and $5 \mathrm{mM} \mathrm{MgCl}_{2}$ ) and buffer D (20 $\mathrm{mM}$ Tris-HCl, $\mathrm{pH} 7.4$, containing $60 \mathrm{mM} \mathrm{KCl}$ and $15 \mathrm{mM} \mathrm{MgCl}_{2}$ ).

Enzymic binding of ${ }^{14} \mathrm{C}-\mathrm{Phe}-\mathrm{tRNA}$ to ribosomes was studied in buffer $\mathrm{C}$ following essentially methods already described using other mammalian systems. ${ }^{13}$ In order to isolate, when required, the complex ribosome- ${ }^{14} \mathrm{C}-\mathrm{Phe}-\mathrm{t}$ RNA (with ${ }^{14} \mathrm{C}-\mathrm{Phe}-\mathrm{tRNA}$ enzymically bound to the ribosomal A-site) the following components were incubated in buffer $\mathrm{A}$ for 30 minutes at $37^{\circ} \mathrm{C}$ in a final volume of $5 \mathrm{ml}$ : $1 \mathrm{mg}$ poly $\mathrm{U}, 250 \mathrm{pCi}$ ${ }^{14} \mathrm{C}-\mathrm{Phe}$-tRNA, $3 \mathrm{mg}$ protein EF 1 preparation, $1 \mu \mathrm{mol}$ GTP and $3.5 \mathrm{mg}$ human tonsil ribosomes. Complex formation was started by addition of GTP. At the end of the incubation period the incubation mixture was chilled on ice and a $50 \mu$ sample was taken to estimate formation of the complex ribosome ${ }^{-14} \mathrm{C}-\mathrm{Phe}-\mathrm{tRNA}$ by Millipore filtration. ${ }^{13)}$ Approximately $12 \%$ of the total ribosomes in the incubation mixture were forming the complex. The total of the chilled mixture was taken and placed over $7 \mathrm{ml}$ of a $10 \%$ sucrose solution in buffer B in $12 \mathrm{ml}$ tubes of the Spinco/Beckman ultracentrifuge and centrifugation was carried out for 3 hours at $105,000 \mathrm{~g}$ at $4^{\circ} \mathrm{C}$. The pellet was carefully rinsed for three times, without removing the pellet, with buffer $B$ and resuspended in $0.5 \mathrm{ml}$ of the same buffer. Absorbancy at $260 \mathrm{~nm}$ and formation of the complex ribosome- ${ }^{11} \mathrm{C}-\mathrm{Phe}-\mathrm{tRNA}$ was then estimated. The complex suspension was stored at $0^{\circ} \mathrm{C}$ and was stable at least for two weeks.

The ribosome ${ }^{-14} \mathrm{C}-\mathrm{Phe}-\mathrm{tRNA}$ complex prepared as described above was used to study translocation. For this purpose $100 \mu \mathrm{lmix}-$ 
tures of buffer $\mathrm{B}$ were used containing 2.4 pmoles ribosome- ${ }^{14} \mathrm{C}-\mathrm{Phe}$-tRNA complex, $70 \mathrm{mg} \mathrm{EF} 2$ and $0.4 \mu$ moles GTP. The reaction was initiated by addition of GTP and incubation carried out for 15 minutes at $37^{\circ} \mathrm{C}$. To stop translocation the reaction mixture was chilled on ice at the end of the incubation period and placed over $12 \mathrm{ml}$ of a $10 \%$ sucrose solution in buffer $\mathrm{B}$ in tubes of the Spinco/Beckman ultracentrifuge and the complex sedimented by centrifugation for 3 hours at $105,000 \mathrm{~g}$ at $4^{\circ} \mathrm{C}$. The pellet was resuspended in $100 \mu$ l buffer $\mathrm{B}$ at $24 \mathrm{pmoles} / \mathrm{ml}$. The extent of the translocation reaction was estimated by the puromycin reaction with this resuspended pellet as described below: Some 20 30\% of the total ${ }^{14} \mathrm{C}-\mathrm{Phe}-\mathrm{tRNA}$ bound was translocated.

Reaction with puromycin of the ribosome${ }^{14} \mathrm{C}-\mathrm{Phe}$-tRNA complex obtained after translocation as indicated above, was studied in $100 \mu$ incubation mixtures in buffer B containing 0.7 pmoles of translocated ribosome${ }^{14} \mathrm{C}-\mathrm{Phe}-\mathrm{tRNA}$ complex and 0.1 umole puromycin. Incubation was carried out for 20 minutes at $37 \mathrm{C}$. Puromycin reaction was terminated by addition of $0.5 \mathrm{ml}$ of ammonium bicarbonate $1 \mathrm{M}, \mathrm{pH} 9$ and the ${ }^{14} \mathrm{C}$ Phe-puromycin formed was extracted with $1 \mathrm{ml}$ ethyl acetate. ${ }^{14}$

Nonenzymic binding of $\mathrm{Ac}-{ }^{14} \mathrm{C}-\mathrm{Phe}-\mathrm{tRNA}$ was studied essentially as previously reported ${ }^{3)}$ by incubation at $37^{\circ} \mathrm{C}$ for 30 minutes in buffer $\mathrm{D}$, poly $\mathrm{U}(2 \mathrm{mg} / \mathrm{ml}), \mathrm{Ac}^{-14} \mathrm{C}-\mathrm{Phe}-$ tRNA $(560 \mathrm{pCi} / \mathrm{ml})$ and ribosomes $(3.5 \mathrm{mg} /$ $\mathrm{ml})$.

One $\mathrm{ml}$ mixtures were incubated during 45 minutes for the purpose of isolating the complex ribosome-Ac- ${ }^{14} \mathrm{C}-\mathrm{Phe}-\mathrm{tRNA}$ and the isolation procedure after the incubation was as described above for the complex ribosome${ }^{14} \mathrm{C}-\mathrm{Phe}-\mathrm{tRNA}$ with the substrate bound to the A-site. Reaction with puromycin of the complex ribosome-Ac- ${ }^{14} \mathrm{C}-\mathrm{Ph}$ - $-\mathrm{RNA}$ was also as indicated above. In the nonenzymic binding of $\mathrm{Ac}^{14} \mathrm{C}-\mathrm{Phe}-\mathrm{tRNA}$ to ribosomes part of the substrate is bound to the $\mathrm{P}$-site as measured by the puromycin reaction but another part is not bound to the $\mathrm{P}$-site. This substrate can be translocated to the P-site by using EF 2 and GTP and separating the translocated complex as described above in the case of the ribosome- ${ }^{14} \mathrm{C}-\mathrm{Phe}-$ tRNA complex. The extent of the translocation reaction was measured by the increase observed in the subsequent study of the puromycin reaction (Table 1 ).

The "fragment reaction" assay in which peptide bond formation takes place, catalysed by human tonsil ribosomes reacting CACAC${ }^{14} \mathrm{C}-\mathrm{Leu}-\mathrm{Ac}$ with puromycin, was carried out as previously described. ${ }^{2}$

Poly U, dithiothreitol and GTP used were from Sigma, 2-mercaptoethanol from Fluka. Millipore HAWP 2400 (from Millipore Corp.) or Sartorius SM 11306 (Membranfilter GmbH) filters were used. Scintillation fluid prepared by diluting $5 \mathrm{~g}$ of butyl-PBD (Ciba) in one liter of toluene was used to measure radioactivity retained by filtration through Millipore filters. To measure ${ }^{14} \mathrm{C}-\mathrm{Phe}-$ or $\mathrm{Ac}-$ ${ }^{14} \mathrm{C}-\mathrm{Phe}$-puromycin extracted by ethyl acetate, a scintillation fluid was used prepared by addition of $250 \mathrm{ml}$ of methoxyethanol to $750 \mathrm{ml}$ of toluene in which $5 \mathrm{~g}$ of butyl PBD ( $\mathrm{Ciba}$ ) have been dissolved previously.

Sources of the protein synthesis inhibitors used in this work were as follows: Actinobolin (Parke Davis), amicetin, chartreusin and cycloheximide (Upjohn), adrenochrome and gougerotin (Calbiochem), anisomycin (Pfizer), aurintricarboxylic acid (ATA) (May and Baker), blasticidin $S$ and bottromycin $A_{2}$ (Institute of Applied Microbiology, Tokyo, Japan), emetine (Wellcome), fusidic acid

Table 1. The puromycin reaction with $\mathrm{Ac}-{ }^{14} \mathrm{C}-\mathrm{Phe}-\mathrm{tRNA}$ bound to ribosomes

\begin{tabular}{l|r|r|c}
\hline \multicolumn{1}{c|}{ Conditions } & $\mathrm{cpm}$ & pmoles & $\begin{array}{c}\text { Translocation } \\
\text { pmoles }\end{array}$ \\
\hline Ribosomes-Ac-14C-Phe-tRNA + puromycin & 717 & 0.82 & - \\
Ribosomes-Ac-14C-Phe-tRNA + EF2 + GTP + puromycin & 1,530 & 1.75 & 0.93 \\
\hline
\end{tabular}

Ac-14C-Phe-tRNA was nonenzymically bound to ribosomes and the complex isolated (2.8 pmoles substrate bound per 16 pmoles ribosomes). The complex was treated with EF 2 and GTP and incubated to translocate the substrate bound to the A-site. The complexes prior or after translocation were treated with puromycin and the Ac- ${ }^{14} \mathrm{C}$-Phe-puromycin formed in both cases was extracted with ethyl acetate. Experimental conditions were as indicated under Materials and Methods. 
(Leo), puromycin (Serva and Nutritional Biochemicals), sparsomycin (National Cancer Institute, Bethesda, USA) and tenuazonic acid (Merck Sharp and Dohme). Edeine $A_{1}$ was a gift from Dr. Z. KuryLo-BorowsKA (Rockefeller University, New York). Pederine was given to us by Prof. M. PAVAN (Institute of Entomology, University of Pavia, Italia). Diphtheria toxin was a gift from Dr. E. BERMEK (Max-Planck Institute for Experimental Medicine, Göttingen, Germany).

\section{Results}

Effect of Protein Synthesis Inhibitors on Substrate Binding to Sites A and $\mathrm{P}$ of the Ribosome

The enzymic binding of ${ }^{14} \mathrm{C}$-Phe-tRNA was carried out to study substrate binding to the A-site of the ribosomes. Our evidence that substrate was bound to the A-site in this assay was that the substrate was not reactive with puromycin after the binding reaction but became reactive (at least $25 \%$ of the bound substrate) after the translocation reaction carried out following the assay described under Materials and Methods. Nonenzymic binding of $\mathrm{Ac}^{14} \mathrm{C}-\mathrm{Phe}-\mathrm{tRNA}$ was also studied and under the experimental conditions used the substrate bound to both the $\mathrm{P}$ - and the $\mathrm{A}$-sites as indicated above.

For the purpose of studying the effect of a number of inhibitors in the binding reac: tion, the required compound was mixed in the incubation mixture with the other components prior to addition of either $\mathrm{Ac}-{ }^{14} \mathrm{C}$ Phe-tRNA or GTP which were added to start the reaction in the nonenzymic or enzymic assay respectively. The results obtained are presented in Table 2. Adrenochrome, ATA and edeine $\mathrm{A}_{1}$ appear to be very effective in blocking binding to both the A- and P-sites of the ribosome. On the other hand although anisomycin, emetine and tenuazonic acid also inhibit to a certain extent binding to the $\mathrm{A}$ - and $\mathrm{P}$-sites this is observed at a rather high concentration of the inhibitors.

Effects of Protein Synthesis Inhibitors on the Translocation Reaction

The translocation reaction was studied with
Table 2. Binding of $\mathrm{Ac}-{ }^{14} \mathrm{C}-\mathrm{Phe}-\mathrm{tRNA}$ and ${ }^{14} \mathrm{C}-\mathrm{Phe}$-tRNA to human tonsil ribosomes. Effects of protein synthesis inhibitors

\begin{tabular}{|c|c|c|c|}
\hline \multicolumn{2}{|c|}{ Additions } & $\begin{array}{l}\text { Ac- }{ }^{14} \mathrm{C}-\mathrm{Phe}- \\
\text { tRNA binding } \\
\text { (\% control) }\end{array}$ & $\begin{array}{c}{ }^{14} \mathrm{C}-\mathrm{Phe}-\mathrm{tRNA} \\
\text { binding } \\
(\% \text { control) }\end{array}$ \\
\hline Adrenochrom & $10^{-4} \mathrm{M}$ & 25 & 23 \\
\hline Anisomycin & $\begin{array}{l}10^{-4} \mathrm{M} \\
10^{-5} \mathrm{M}\end{array}$ & $\begin{array}{l}58 \\
99\end{array}$ & $\begin{array}{l}51 \\
91\end{array}$ \\
\hline ATA & $10^{-4} \mathrm{M}$ & 1 & 15 \\
\hline Edeine $A_{1}$ & $10^{-6} \mathrm{M}$ & 26 & 14 \\
\hline Emetine & $10^{-4} \mathrm{M}$ & 53 & 74 \\
\hline $\begin{array}{l}\text { Tenuazonic } \\
\text { acid }\end{array}$ & $\begin{array}{l}10^{-3} \mathrm{M} \\
10^{-4} \mathrm{M}\end{array}$ & $\begin{array}{l}67 \\
96\end{array}$ & $\begin{array}{l}61 \\
92\end{array}$ \\
\hline
\end{tabular}

Assays were carried out using human tonsil ribosomes under the experimental conditions described above. Figures given in this Table are percentage of control reactions in the absence of inhibitor. Binding of Ac-14C-Phe-tRNA in the control reactions was 1.6 pmoles whereas ${ }^{14} \mathrm{C}-\mathrm{Phe}-\mathrm{t} R \mathrm{NA}$ binding was 2.4 pmoles. The following compounds produced no effect or only a marginal difference from the controls in the above reaction assays: Actinobolin $\left(10^{-4} \mathrm{M}\right)$, amicetin $\left(10^{-4} \mathrm{M}\right)$, blasticidin $\mathrm{S}\left(2 \times 10^{-4} \mathrm{M}\right)$, bottro mycin $\mathrm{A}_{2}\left(10^{-3} \mathrm{M}\right)$, chartreusin $\left(2 \times 10^{-4} \mathrm{M}\right)$, cycloheximide $\left(10^{-4} \mathrm{M}\right)$, diphtheria toxin $(125 \mathrm{\mu g} / \mathrm{ml}$ always assayed in the presence of $10^{-5} \mathrm{M}$ NAD), gougerotin $\left(10^{-4} \mathrm{M}\right)$, pederine $\left(2 \times 10^{-5} \mathrm{M}\right)$ and sparsomycin $\left(10^{-4} \mathrm{M}\right)$.

Table 3. Translocation of Ac- ${ }^{14} \mathrm{C}-\mathrm{Phe}-\mathrm{tRNA}$ and ${ }^{14} \mathrm{C}-\mathrm{Phe}-\mathrm{RNA}$ bound to human tonsil ribosomes. Effects of protein synthesis inhibitors

\begin{tabular}{c|c|c}
\hline Additions & $\begin{array}{c}\text { Ac-14C-Phe- } \\
\text { tRNA } \\
\text { translocation } \\
(\% \text { control })\end{array}$ & $\begin{array}{c}14 \mathrm{C}-\text { Phe-tRNA } \\
\text { translocation } \\
(\% \text { control })\end{array}$ \\
\hline $\begin{array}{c}\text { Cycloheximide } \\
10^{-4} \mathrm{M}\end{array}$ & - & 88 \\
$\begin{array}{c}\text { Diphtheria toxin } \\
125 \mu \mathrm{g} / \mathrm{mI}\end{array}$ & 36 & 11 \\
$\begin{array}{c}\text { Fusidic acid } \\
5 \times 10^{-3} \mathrm{M} \\
2 \times 10^{-4} \mathrm{M}\end{array}$ & 115 & - \\
$\begin{array}{r}\text { Pederine } 2 \times 10^{-5} \mathrm{M} \\
2 \times 15\end{array}$ & 32 & 30 \\
\hline
\end{tabular}

Assays were carried out using human tonsil ribo somes under the experimental conditions indicated under Materials and Methods. Figures given in this Table are percentage of control reactions in the absence of inhibitors. Average of Ac-14C-Phe-tRNA translocated in the controls was 0.8 pmoles $(47 \%$ of the total substrate bound) whereas ${ }^{14} \mathrm{C}-\mathrm{Phe}$-tRNA translocated in the control was 0.6 pmoles $(21 \%$ of the total substrate bound).

The following compounds produced no effect or only a marginal difference from the controls in the above reation assays: Actinobolin $\left(10^{-4} \mathrm{M}\right)$, amicetin $\left(10^{-4} \mathrm{M}\right)$, ađrenochrome $\left(10^{-4} \mathrm{M}\right)$, anisomycin $\left(10^{-4} \mathrm{M}\right)$, ATA $\left(10^{-4} \mathrm{M}\right)$, blasticidin $S\left(2 \times 10^{-4} \mathrm{M}\right)$, bottromycin $A_{2}\left(10^{-4} \mathrm{M}\right)$, chartreusin $\left(2 \times 10^{-4} \mathrm{M}\right)$, edeine $\mathrm{A}_{1}\left(10^{-6} \mathrm{M}\right)$, emetine $\left(10^{-4} \mathrm{M}\right)$, gougerotin $\left(10^{-4} \mathrm{M}\right)$, sparsomycin $\left(10^{-4} \mathrm{M}\right)$ and tenuazonic acid $\left(10^{-4} \mathrm{M}\right)$.

either ${ }^{14} \mathrm{C}-\mathrm{Phe}-\mathrm{tRNA}$ enzymically bound (in this binding reaction all the substrate was bound to the A-site) or $\mathrm{Ac}-{ }^{14} \mathrm{C}-\mathrm{Phe}-\mathrm{tRNA}$ 
nonenzymically bound (in this binding reaction part of the substrate was bound to the A-site). To test the effect of the different compounds in translocation they were added to the incubation mixture before addition of GTP and the mixture preincubated for 10 minutes at $37^{\circ} \mathrm{C}$ to facilitate inhibitor binding before starting the translocation reaction by addition of GTP. The effect of protein synthesis inhibitors on the transiocation reaction is shown in Table 3. In both systems used there is a clear inhibition in the translocation step by diphtheria toxin and pederine. However no inhibition was found in the in the presence of fusidic acid.
Table 4. Peptide bond formation by human tonsil ribosomes. Effects of protein synthesis inhibitors

\begin{tabular}{|c|c|c|c|c|}
\hline & & $\begin{array}{c}\text { Ac-14 } \mathrm{C}-\mathrm{Phe}-\overline{\mathrm{Pur}} \\
\text { formation } \\
(\% \text { control })\end{array}$ & $\begin{array}{c}11 \mathrm{C}-\mathrm{Ph} \text {-Pur } \\
\text { formation } \\
(\% \text { control })\end{array}$ & $\begin{array}{c}\text { Fragment } \\
\text { reaction } \\
(\% \text { control })\end{array}$ \\
\hline Actinobolin & $\begin{array}{l}10^{-4} \mathrm{M} \\
10^{-3} \mathrm{M}\end{array}$ & 94 & - & $\begin{array}{l}75 \\
29\end{array}$ \\
\hline Amicetin & $\begin{array}{l}10^{-4} \mathrm{M} \\
10^{-3} \mathrm{M}\end{array}$ & $\begin{array}{l}95 \\
74\end{array}$ & - & - \\
\hline Anisomycin & $10^{-4} \mathrm{M}$ & 25 & 16 & 5 \\
\hline Blasticidin S 2 & $\begin{array}{r}2 \times 10^{-4} \mathrm{M} \\
10^{-4} \mathrm{M}\end{array}$ & - & 23 & $\overline{12}$ \\
\hline Cycloheximide & $10^{-4} \mathrm{M}$ & - & 93 & - \\
\hline Gougerotin & $\begin{array}{l}10^{-4} \mathrm{M} \\
10^{-3} \mathrm{M}\end{array}$ & 97 & - & $\overline{16}$ \\
\hline Sparsomycin & $10^{-4} \mathrm{M}$ & 21 & 19 & 7 \\
\hline Tenuazonic acid & $\begin{array}{l}10^{-4} \mathrm{M} \\
10^{-3} \mathrm{M}\end{array}$ & $\begin{array}{l}98 \\
51\end{array}$ & 50 & $\begin{array}{l}73 \\
22\end{array}$ \\
\hline
\end{tabular}

Assays were carired out using human tonsil ribosomes under the experimental conditions described above. Figures given in this Table are percentage of control reactions in the absence of inhibitor. In the control assays 1.75 pmoles Ac-14C-Phe-Pur or 0.68 pmoles ${ }^{14} \mathrm{C}$-Phe-Pur were formed in the puromycin reaction and 1.39 pmoles Ac-14C-Phe-puromycin were formed in the fragment reaction assay. The following compounds produced no effect or only a marginal difference from the controls in the above reaction assays: Adrenochrome $\left(10^{-4} \mathrm{M}\right)$, ATA $\left(10^{-4} \mathrm{M}\right)$, bottromycin $\mathrm{A}_{2}\left(10^{-4} \mathrm{M}\right)$, chartreusin $\left(2 \times 10^{-4} \mathrm{M}\right)$, edeine $\mathrm{A}_{1}\left(10^{-6} \mathrm{M}\right)$, emetine $\left(10^{-4} \mathrm{M}\right)$, diphtheria toxin $\left(125 \mathrm{\mu g} / \mathrm{ml}\right.$ in the presence of $10^{-5} \mathrm{M}$ NAD), fusidic acid $\left(2 \times 10^{-4} \mathrm{M}\right)$, and pederine $\left(10^{-4} \mathrm{M}\right)$. $(-)$ shows that the indicated experiment has not been performed.

\section{Effects of Protein Synthesis Inhibitors on Peptide \\ Bond Formation}

The effect of protein synthesis inhibitors on peptide bond formation was tested in the following experimental systems: (a) puromycin reaction with ${ }^{14} \mathrm{C}-\mathrm{Phe}-\mathrm{t} R \mathrm{RA}$ prebound enzymically to the A-site and translocated to the P-site prior to addition of puromycin, (b) puromycin reaction with $\mathrm{Ac}^{14} \mathrm{C}-\mathrm{Phe}-$ tRNA after nonenzymic binding and translocation to position all the substrate in the $\mathrm{P}$-site and (c) ribosome catalysed puromycin reaction with $\mathrm{CACCA}-{ }^{14} \mathrm{C}-\mathrm{Leu}-\mathrm{Ac}$ ("fragment reaction"). In all cases the protein synthesis inhibitors were preincubated with the incubation mixtures for 10 minutes at $37^{\circ} \mathrm{C}$ prior to addition of puromycin to start the reaction. The results obtained in these experiments are presented in Table 4 . The results obtained comparing the effect of the different protein synthesis inhibitors in the three systems used are rather in good agreement but the "fragment reaction" appears to be the most sensitive assay to test peptide bond formation inhibitors.

\section{Discussion}

The results presented in this contribution show that in human tonsil ribosomes we have a good system to study: substrate binding to the $\mathrm{P}-$ and $\mathrm{A}$-sites of ribosomes, translocation and peptide bond formation.

ATA and edeine $A_{1}$ were confirmed in this work to be good inhibitors of substrate binding to the ribosome; this finding has repeatedly been observed in other systems ${ }^{4,15)}$. In addition we found that adrenochrome is an efficient inhibitor of substrate binding.

Diphtheria toxin and pederine have been clearly shown in this work to be specific inhibitors of translocation. Diphtheria toxin has been assumed in the past years to be an inhibitor of translocation since it acts on EF 2 causing its ADP-ribosylation. However, it has recently been observed that the ADP-ribosyl-EF 2 formed can bind to the ribosome $\mathrm{e}^{16)}$ and activate the normal EF 2and ribosome-dependent GTPase required in translocation. ${ }^{17)}$ So it is interesting our observation that diphtheria toxin inhibits the translocation step uncoupling it from GTP hydrolysis. We consider very interest- 
ing. our finding that pederine blocks translocation in the well resolved systems that we have used since this has not been observed previously, although on the basis of some indirect evidence pederine has certainly been postulated as an inhibitor of translocation. ${ }^{18)}$ On the other hand cycloheximide and fusidic acid do not inhibit translocation in our experimental system. Cycloheximide has previously been reported as an inhibitor of translocation on the basis that it inhibited the increase observed on the puromycin reaction with mammalian polysomes when EF 2 and GTP were added. ${ }^{19,20)}$ The inhibitory effect of cycloheximide on translocation has also been reported in a resolved reticulocyte system ${ }^{21)}$ and certainly we cannot understand at the present time the reason for this result differing from those which we present in Table 3 concerning cycloheximide action. Fusidic acid has been reported as an inhibitor of translocation on bacterial ${ }^{22,23}$ as well as mammalian systems. ${ }^{24}$ ) This reported inhibition of fusidic acid on translocation was based on either inhibition of GTPase or inhibition of translocation in model systems in certain experimental conditions. However recent experimental evidence in bacterial systems has shown that fusidic acid is not really an inhibitor of translocation ${ }^{25,26,27,287}$ and this is also confirmed in this work in a mammalian system.

Anisomycin, sparsomycin and tenuazonic acid have been shown in this work to be good inhibitors of peptide bond formation in all the different experimental systems used. We have already reported inhibition of peptide bond formation by anisomycin and sparsomycin in different eukaryotic systems ${ }^{1,2,3)}$ but an inhibitory effect of tenuazonic acid on peptide bond formation is described in this contribution for the first time. It is interesting our observation that tenuazonic acid is a good inhibitor of peptide bond formation in mammalian systems but not in yeast. ${ }^{3)}$

The antibiotics actinobolin, blasticidin $\mathrm{S}$ and gougerotin were found in this work to be very poor inhibitors of peptide bond formation in our model systems for the puromycin reaction but were quite active in blocking peptide bond formation in the frag- ment reaction which is a more resolved system. We have previously found a similar situation in the case of yeast ribosomes. ${ }^{3)}$

The antibiotic amicetin was found in this work to be a very poor inhibitor of peptide bond formation in the two systems used. We have obtained a similar finding in yeast ribosomes but in this case amicetin was quite active in blocking peptide bond formation in the fragment reaction assay performed with $60 \mathrm{~S}$ subunits ${ }^{3)}$. This type of experiment was not carried out in this work.

\section{References}

1) Vazquez, D.; E. Battaner, R. Neth, G. HELLER \& R. E. MONRo: The function of $80 \mathrm{~S}$ ribosomal subunits and effects of some antibiotics. Cold Spring Harb. Symp. Quant. Biol. $34: 369 \sim 375,1969$

2) Neth, R.; R. E. Monro, G. Hetier, E. Battaner \& D. VazQuez: Catalysis of peptydil transfer by human tonsil ribosomes and effects of some antibiotics. FEBS Letters $6: 198 \sim 202,1970$

3) BatTANER, E. \& D. VAZQUEZ: Inhibitors of protein synthesis by ribosomes of the $80 \mathrm{~S}$ type. Biochim. Biophys. Acta $254: 316 \sim$ 330,1971

4) PestKa, S.: Inhibitors of ribosome functions. Ann. Rev. Microbiol. $25: 487 \sim 562$, 1971

5) Neth, R., G. Heller \& H. Mattaei : Präparation von Ribosomen, Transfer-RNASynthetasen aus Operations-- und Biopsiematerial. HoPPE-SEYleR's Z. Physiol. Chem. $349: 1514 \sim 1524,1968$

6) Bermeк, E. \& H. Matтhaei: Elongation factors from human lymphatic tissue isolation and some properties. FEBS Letters $10: 121 \sim 124,1970$

7) Galasinski, W. \& K. Moldave: Purification of aminoacyl transferase II (Translocation Factor) from rat liver. J. Biol. Chem. $244: 6527 \sim 6532,1969$

8) Carrasco, L.; E. Battaner \& D. Vazquez: The elongation steps in protein synthesis by eukaryotic ribosomes: Effects of antibiotics. (In press)

9) Bermek, E. \& H. Matthaei : Interactions between human translocation factor, guanosine triphosphate and ribosomes. Biochemistry $10: 4906 \sim 4912,1971$

10) Conway, T. W.: On the role of ammonium or potassium ion in amino acid polymerization. Proc. Nat. Acad. Sci. $51: 1216 \sim 1220$, 1964 
11) Haenni, A. L. \& F. Chapeville: The behaviour of acetyl phenylalanyl soluble ribonucleic acid in polyphenylalanine synthesis. Biochim. Biophys. Acta 114 : 135 148, 1966

12) Schneider, D.; R. SOLFert \& F, VON DER $\mathrm{H}_{\text {AAR }}$ : Large scale purification of tRNA ${ }^{\mathrm{Ser}}$, tRNA ${ }^{\mathrm{Tyr}}$ and tRNA ${ }^{\text {Phe }}$ from baker's yeast. Hoppe-Seyler's Z. Physiol. Chem. 353: 1330 1336, 1972

13) MatthaeI, J. H. \& G. H. Schoech : Human gene expression. I. An aminoacyl-RNA binding system from human placenta. Biochem. Biophys. Res. Commun. $27: 638 \sim 643,1967$

14) Leder, P. \& H. Bursztyn : Initiation of protein synthesis. II. A convenient assay for the ribosome-dependent synthesis of $\mathrm{N}$-formyl-C $\mathrm{C}^{14}$-methionyl-puromycin. Biochem. Biophys. Res. Commun. 25:233 238,1966

15) Obrig, T.; J. Irvin, W. Culp \& B. Hardesty : Inhibition of peptide initiation on reticulocyte ribosomes by edeine. Europe. J. Biochem. $21: 31 \sim 41,1971$

16) Bermek, E. : Formation of a complex involving ADP-ribosylated human translocation factor, guanosine nucleotide and ribosomes. FEBS Letters $23: 95 \sim 99,1972$

17) Thboni, O. \& O. Ciferri : Selective inhibition of the reactions catalyzed by ribosomespecific tranfer factors G. FEBS Letters 19 : $174 \sim 179,1971$

18) Jacobs-Lorena, M.; A. Brega \& C. Baglionx: Inhibitors of protein synthesis in reticulocytes by antibiotics. V. Mechanisms of action of pederine, an inhibitor of initiation and elongation. Biochim. Biophys. Acta $240: 263 \sim 272,1971$

19) Baliga, B. S.; A. W. Pronczuk \& H. N. Munro: Mechanism of cycloheximide inhibition of protein synthesis in a cell-free system prepared from rat liver. J. Biol. Chem. 244: 4480 4489, 1969

20) McKeghan, W. \& B. Hardesty: The mechanism of cycloheximide inhibition of protein synthesis in rabbit reticulocytes. Biochem. Biophys. Res. Commun. 36:625 630, 1969

21) Obrig, T.G.; W. J. Culp, W. L. McKeehaN \& B. Hardesty : The mechanism by which cycloheximide and related glutarimide antibiotics inhibit peptide synthesis on reticulocyte ribosomes. J. Biol. Chem. $246: 174 \sim$ 181, 1971

22) Haenni, A. L. \& J. Lucas-Lenard : Stepwise synthesis of a tripeptide. Proc. Nat. Acad. Sci. $61: 1363 \sim 1369,1968$

23) Tanaka, N.; T. Krnoshita \& H. Masukawa: Mechnanism of protein synthesis inhibition by fusidic acid and related antibiotics. Biochem. Biophys. Res. Commun. 33: 769 773,1968

24) Malkin, M. \& F. Lipmann: Fusidic acid : Inhibition of factor $\mathrm{Tu}$ in reticulocyte protein symthesis. Science 164:71 72, 1969

25) Modolet. L, J. \& B. D. Davies: Significance of the effect of streptomycin and fusidic acid on polysome stability. Progress in Antimicrobial and Anticancer Chemotherapy. Vol. II, p. 464, University of Tokyo Press, Tokyo, 1970

26) Cundiffe, E. : The mode of action of fusidic acid. Biochem. Biophys. Res. Commun. 46: 1794 1801, 1972

27) Cabrer, B.; D. VazQuez \& J. Modolfelil : Inhibition by elongation factor EF $G$ of aminoacyl-tRNA binding to ribosomes. Proc. Nat. Acad. Sci. 69 : 733 736, 1972

28) Celma, M. L.; D. VAzquez \& J. Modolell : Failure of fusidic acid and siomycin to block ribosomes in the pretranslocated state. Biochem. Biophys. Res. Commun. $48: 1240 \sim$ 1246, 1972 